\title{
THE FERMI CHICAGO PILE
}

$\mathrm{O}^{\mathrm{N}}$ December 2, 1942, at 3.25 p.m. Chicago time, the first self-sustaining nuclear chain reaction was initiated and controlled. The success of the experiment was mainly due to Enrico Fermi. He directed the construction and the operation of the pile situated in the West Stands, Stagg Field, University of Chicago, in what had been a squash-rackets court. To mark tho twentieth anniversary of this historical occasion and as a tribute to the memory of Enrico Fermi the International Atomic Energy Agency has issued a special number of its Bulletin (December 2, 1962) containing an introductory article by S. Eklund, director general of the Agency, and thirteen other articles, by distinguished scientists, devoted to descriptions of the first atomic pile or developments in the field of nuclear energy in various countries. English, French, German, Russian and Spanish editions of the Bulletin are to be published.

In his introductory remarks, the director general comments that immediately after the Second World War when the basic knowledge of atomic energy spread all over the world it was thought that the new source of energy could be put to widespread practical use within a very short time. But now, twenty years after the first reactor was put into operation, we have learned that development in nuclear energy must follow the same sequence as in every other major technological advance and involve only small steps at a time. The introduction of nuclear power will not be a sudden event, but instead a gradual process. However, the bonefits already accruing from radioisotopes, an important by-product of nuclear energy, and their wide use in research and industry, require especial mention.

All the articles, except the simple descriptive account of the first atomic pile entitled "The First Pile" by C. Allardice and E. R. Trapnell, which was written in 1946 and is reprinted in the Bulletin, are original contributions. They include a brief personal account by Laura Fermi of her husband during the period he was working on the so-called 'metallurgical project' and of the absolute secrecy he maintained, even from her, of the work he was doing. Lise Meitner writes about the right and wrong roads to the discovery of nuclear energy; Otto Hahn on "Enrico Fermi and Uranium Fission"; H. D. Smyth on the publication of the "Smyth Roport"; S. K. Allison on the "Initiation of the Chain Reaction" and his own particular task, the search for pure materials required for the pile; and G. T. Seaborg on the production of plutonium and its chemical extraction. Sir John Cock. croft describes the early days of the Canadian and British atomic energy projects. B. Goldsohmirt discusses France's contribution to the discovery of the chain reaction and shows that the work of French scientists, while it did not contribute directly to the success of December 2, 1942, did nevertheless back up the efforts of Great Britain to persuade the United States to tackle the uranium problem on an industrial scale, and played a large part in the birth of nuclear activities in Canada and in the dovelopment of heavy water reactors. V. S. Emelyanov gives some historical details of the study of radioactive materials, and uranium, and graphite, by Soviet scientists leading up to the production of uranium and graphite for the first atomic reactor in the U.S.S.R.

In his article entitled "Thoughts on the 20th Anniversary of $C P-1$ " E. P. Wigner states that on the memorable occasion of December 2, 1942, the scientists involved in the nuclear project realized that both the economic and political world would be affected by their great achievement. Economically they thought that the main effect would be cheaper onergy, but so far this objective has not been realized. In the political field they hoped and expected that the terrible nature of nuclear weapons would have such a sobering effect on the Governments of all nations that they would forsake their conflicting aspirations and submit to a larger community of law and order. This was based on a misunderstanding. The issues of war and peace are governed not by the nature of weapons but by the conflicting desires of Governments.

The remaining two articles are by J. A. Wheeler and G. de Hevesy, who discuss "Fission, Then and Now" and "The Reactor and the Production of Isotopes", respectively.
S. Weintroub

\section{THE BRITISH COUNCIL}

$\mathrm{T}$ HE annual report for 1961-62 of the British Council * is in two parts, the general survey of the year being accompanied by an article "Teaching Courses" which, besides describing the Council's part in recruiting British teachers to serve overseas, seeks to answer some questions asked by potential candidates for overseas teaching posts. In addition to filling teaching posts in its own permanent service the Council recruited 226 teachers on short-term contract, of which 140 were for schools and 45 for universities and training colleges, about 25 per cent of those in universities being at the professorial level and rather more than half in English departments. Most of the Council's educational work in doveloping countries is complementary to technical co-operation, and experience in Nigeria and Ghana has clearly indicated that the opportunities open to the Council for educational workespecially in English language teaching-increase as the number of expatriate civil servants decreases. Arrangements have already been made for collaboration with the Department of Technical Co-operation in Nigeria which

* The British Council. Annual Report, 1961-1962. Pp. vii +107+12 * The British Council. Annual Report, 1961-1962.
plates. (London: The British Council, 1962.) 2s. $6 d$. net. may become tho pattern for similar co-operation elsewhere in Africa.

The Council's English Teaching Information Centre, formed in 1960 to collect and co-ordinate experience and information about teaching English as a second or foreign language, now distributes about 1,000 copies of its EnglishTeaching Abstracts and English-Teaching Bibliography in more than ninety countries. Moreover, the Council has maintained close contact with the British Broadcasting Corporation and with the Centre for Educational Television Overseas in its investigations on the production of English language teaching films for television and for classroom work. A substantial financial contribution is being made towards the running costs over the next five years of the English schools in Nicosia; $£ 34,000$ was contributod for a library building in Port Harcourt, Eastern Nigeria; $£ 12,000$ towards one at Kaduna, Northern Nigeria; a grant of $£ 35,000$ was made to the Sierra Leono Library Board towards the capital cost of a Central Library and headquarters building in Freetown; late in $1961, £ 27,000$ was granted towards the establishment of a central and headquarters library at Ibadan, Western Nigeria. In 
all, during two and a half years, grants totalling $£ 175,000$ have been allocated for library development in seven centres.

There are now estimated to be somo 60,000 overseas students in Britain and during the year the Council met and assisted 10,407 on arrival, of whom 5,127 wore from the Commonwealth and 3,601 were colonial. Permanent accommodation was arranged for 320 in Council residences, 874 in university and other hostels or halls of residence, and 6,301 in lodgings, as well as transit accommodation on first arrival for more than 4,500 and temporary accommodation when away from place of study for nearly 7,000 . Hospitality was arranged for and accepted by 13,547, more than 20,000 attended week-end courses, study visits and surveys, nearly 2,500 holiday courses of 7-15 days, more than 12,000 Council centres and 4,000 introduction courses. With the capital fund of $£ 3$ million which the Council is administering for the Government, a target of an additional 5,000 hostel places has been set, wherevor possible by voluntary societies and other organizations, and 37 projects for hostel development (providing an additional 1,382 places) have been approved. There are also plans for some expansion of the Council's social and cultural centres for overseas students and trainees. About half the overseas students and trainees in Britain are studying some branch of science, technology or medicine and about half the advisory visits arranged by the Council overseas are concerned with these subjects.

Of 7,522 overseas visitors in Britain assisted by the Council (including 646 Colombo Plan trainees, 633 United Nations Fellows and 378 Scholars and 416 TeacherBursars under the Commonwealth Educational Co-operation), 1,030 were in medicine, 1,717 in science and technology and 1,535 in social science. Besides 73 university interchange visits (54 to Britain) arranged under the Commonwealth Scheme, 134 short visits wore arranged under the Foreign Scheme (65 to Britain) as well as 4 longer teaching visits by guest professors and lecturers to university departments, and 99 visits of younger research workers between British and foreign universities ( 53 to Britain). In all 358 specialist tours, advisory visits and delegations were arranged during the year, of which 52 were in science and technology, 51 in medicine and 25 in social science, and the Council assisted in the selection of candidates for 113 scholarships offered to British students in 21 centres.

\section{THE NATURE CONSERVANCY}

$\mathrm{T}$ HE thirteenth annual report of the Nature Conservancy for the year ended September 30, 1962*, records a total of 100 National Nature Reserves with an acreage exceeding 190,000, and the Conservancy has thus completed the greater part of its original acquisition programme of some 140 reserves and an aroa of about 250,000 acres. Difficult acquisition problems are presented by some of the proposed reserves and completion may still be considerably dolayed. However, these figures do not include some nine local and eleven forest nature reserves or two wildfowl refuges, many more of which will be required, but it is already clear that the programme set forth in 1947 in the report of the Wild Life Conservation Special Committee was fundamentally sound.

With the substantial progress in acquisition, the focus of effort shifts progressively from the acquisition of reserves and their rehabilitation to the formulation of comprehensive plans of management and the development of research projects, although the report refers to progress during the year in making management plans as disappointing. On the other hand, encouraging progress is reported in working co-operative arrangements, particularly with the new county naturalists' trusts which are emerging on a national scale as effective organizations for acquiring reserves and furthering conservation. A much wider spread of informed public interest is, however, desirable, although the launching of the British national appeal for the World Wildlife Fund has oncouraged hopes of placing the voluntary movement on a firmer basis. Conservation requires large financial and practical support from voluntary sources and this requires education, guidance and self-restraint by eitizens, which are imbued preferably through voluntary and elected bodies.

Nevertheless, despite encouraging indications of growing co-operation and such signs of progress as the issue of the Conservanay's first monograph, Plant Communities of the Scottish Highlands (seo Nature, 196, 206; 1962), the striking advance in the amount of advice on specific problems, such as toxie chemicals and wildlife, provided for authorities and organizations concerned, a careful reading of the report suggests that the national contribution to conservancy is too small. The report itself admits to a difficult year financially. The grant-in-aid

* The Nalure Conservancy. Report of the Nature Conservancy for the * The Nalure Conservancy. Report of the Nature Conservancy for the
year ended 3nth September, 1962. Pp. viii $+153+15$ plates. (London:
H.M.S.O., 1962.) 10s. net. was $£ 535,000$, of which $£ 465,000$ was for goneral purposes and $£ 70,000$ for capital expenditure. Receipts amounted to just more than $£ 14,000$, but it was necessary to transfer $£ 14,000$ from the capital expenditure to the general expenses account, and the increase of $\$ 55,000$ in the income for $1962-63$ is almost entirely absorbed by rising salaries and general expenses. Expenditure on research, training and special surveys amounted to no more than $£ 76,626$, of which $£ 33,782$ was for grants and research and $£ 22,149$ for studentships and training grants, figures which compare with $£ 65,414, £ 28,965$ and $£ 18,428$, respectively, in 1960-61.

In this connexion, a sub-committoe under the chairmanship of Prof. W. H. Pearsall, after reviewing the responsibilities of the Conservancy for grant-aided research, including the present status of biological research and of support for all aspects of ecology, concluded that the Conservancy's responsibilities should be broadened. This would permit stronger liaison with the universities, the desirability of which was emphasized by the Solect Committee on Estimates in its 1957-58 report, and would provide greater and moro flexible support for research into natural biological resources and the fundamental aspects of biology underlying it. The Conservancy has accepted this recommendation in principle, but its implementation depends on the outcome of other current reviews of Government support for biological sciences. Eight new grants were approvod during the year and ten existing grants renewed or extended. Provision for research studentships is also at present under review; fourteen awards were made during the yoar and thirteen applications for third-year extensions were approved. Six awards were again made for the one-year diploma course on conservation.

A feature of the report is the increasing attention given to international and overseas activities. The Conservancy is an active member of the International Union for the Conservation of Nature and Natural Resources, and besides reporting on meetings of the Commissions on Ecology and on Education of that body, the present report includes notes on the first world conference on national parks at Seattle, the International Council for Bird Preservation, the thirteenth International Ornithological Congress, the fifteenth Limnological Congress, and an international conference in May 1962 at which the feasibility was agreed of an International Biological Pro- 